\title{
Unwanted Childlessness and NRTs in Italy: Biology and Sociality in a Political and Infra-political Struggle
}

\section{Ilaria Lesmo}

PhD student at University of Milano-Bicocca

i.lesmo@campus.unimib.it

Lesmo, Ilaria. (2013). Unwanted Childlessness and NRTs in Italy: Biology and Sociality in A Political and Infra-political Struggle. Tidsskrift for Forskning i Sygdom og Samfund, nr. 19, 27-53.

This article explores the way in which people with unwanted childlessness who are undergoing the New Reproductive Technologies (NRTs) interpret and experience such technologies and their own affliction after the approval of Law 40/2004 (the first Italian law ruling NRTs' usage). The work is grounded on an ethnographic research carried out between 2005 and 2008: in that period Law 40/2004 had just been approved and the Country was facing a socio-economical crisis. This paper specifically focuses on the narratives of seven people (six women and a man) with unwanted childlessness, whose accounts were collected during the fieldwork. Those people had undergone NRTs just before or immediately after the approval of the law.

The exploration of their narratives shows, in the first place, that unwanted childlessness can be considered as a socially produced disorder in a context of structural violence. In fact, the affliction proves to be the embodied answer to limiting socio-economical conditions, further sharpened by the law's obligations. 
Secondly, the analysis depicts some infra-political practices performed by people with unwanted childlessness in order to react to the situation. The work particularly underlines that those people devised some strategies - both symbolic and practical ones - in order to exert their own agency.

In conclusion, unwanted childlessness results to be an embodied commentary on the structural violence imposed on some people by socio-economical conditions. From that situation of violence, new representations, and new practices have arisen, aiming to oppose the constraints which burden some reproductive experiences.

\section{Introduction}

On March 10th, 2004 the first law regarding NRTs (Law 40/2004) ${ }^{1}$ became effective in Italy. After the approval of this law, debates about NRTs increased. Politicians, scholars of various disciplines, health care professionals as well as the grassroots discussed such technologies during several public and media events. However, the perspective of NRTs' clients was rarely considered. This paper aims to explore, from an anthropological point of view, the experiences of people with unwanted childlessness who underwent NRTs in the Italian context.

First of all, the work analyses how people with unwanted childlessness interpreted their own affliction, as well as Law 40/2004, and how they related them to some socio-cultural processes. As the paper will show, the concepts of "embodiment" and "structural violence" are useful analytical tools in order to show how the subjective experiences and the socio-cultural context have reciprocally shaped one another.

In the second place, the article examines the practices performed by subjects with unwanted childlessness undergoing NRTs. These people have usually accused the groups in power of limiting the reproductive chances of people already suffering from reproductive limitation. In reaction to this situation, they carried out some creative strategies. The concept of "infrapolitics" is pivotal in order to understand such strategies, which allowed these people to exert their own agency within an arena of reproductive constraints. Particularly, the manipulation and the resemantization of some technologies result to be very important in their attempts.

The paper starts with the description of the ethnographic method adopted in the fieldwork. Subsequently, it proposes a theoretical framework, specifically drawn from medical anthropology and anthropology of reproduction. A short description of Italian socio-political processes and of the origins of Law 40/2004, 
follows. Finally, the narratives of some people with unwanted childlessness are explored: Firstly, the analysis focuses on the experiences of unwanted childlessness and of NRTs' practices. In the second place, it depicts some infrapolitical strategies performed by people with unwanted childlessness in reaction to the law's impositions.

\section{Methods}

This work is grounded on the narratives of five women and a married couple (a woman and a man) with unwanted childlessness, who underwent different kinds of NRTs. These narratives have been collected during an ethnographic research carried out in Turin (Italy) between 2005 and 2008. For that research, I contacted a gynaecologist who works in a private fertility clinic, and he introduced me to twelve clients of his. These women then allowed me to come into contact with other people with unwanted childlessness. In all, the stories of nineteen Italian women and two Italian men who underwent various kinds of reproductive practices have been collected.

This paper refers to the stories of five of these women (Fabiana, Luisa, Elisa, Bruna and Sabina ${ }^{2}$ ) and of a married couple (Anna and Giovanni). These accounts have been chosen for two reasons: Above all, the stories they told me specifically focus on the interconnection between socio-cultural processes and unwanted childlessness. Moreover, this selection encompasses a wide range of different experiences, with regards to: (a) Biomedical diagnosis; (b) therapeutic paths; (c) the period during which they underwent NRTs (before/after the approval of Law 40/2004); (d) how these people have been contacted. The fact of considering so varied situations shows that the interviewed people activated similar discourses (about social production of childlessness, socio-economical violence, and legitimate usages of NRTs) independently of their different paths.

Mainly, the subjects were affected by conditions categorized by different biomedical diagnoses (a): Idiopathic infertility was diagnosed in three cases, bilateral tubal obstruction in one case, early menopause in one case, and secretory azoospermia in one case.

These people also underwent different therapeutic paths (b): Fabiana had some intrauterine inseminations (IUI), before trying two cycles of in vitro fertilizations (IVF). She turned to two different clinics, but she never cryopreserved embryos. She gave birth to twins after the second attempt. Luisa was pregnant after her first in vitro fertilization, when she had a daughter. She could have cryopreserved 
many embryos, since at that time Law 40/2004 had not been approved yet. After a few years, she decided to undergo an embryos implantation and she gave birth to twins. Elisa became the mother of a set of triplets at her second in vitro fertilisation. Also in this case, many embryos could have been cryopreserved. Sabina tried IUI many times, always ineffectively. Some years later, she entered a new clinic where a doctor suggested her in vitro fertilization. Sabrina was pregnant at the third attempt and she gave birth to twins. Bruna, and Anna and Giovanni had to undergo a donation of gametes. Since the law (which had already been approved) banned this practice, they had to go abroad. Bruna was pregnant at her first embryos implantation, while Anna and Giovanni had to wait three in vitro fertiliszations with embryo cryopreservation, before having twins.

As anticipated, even the period during which these people underwent NRTs varies (c): Luisa and Elisa experienced NRTs before the enactement of Law 40, while Fabiana, Bruna and Sabina tried them after the law's promulgation. The path of Anna and Giovanni was more complex, since they underwent NRTs both before and after the approval of the law.

Referring to how these people have been contacted (d), five women were introduced to me by the above mentioned gynaecologist, while I met the married couple thanks to the introduction of a friend of theirs, who was suffering from unwanted childlessness too.

When I met each of them, they all had managed to give birth at least to one child. I visited all of them once or twice at their house or at their workplaces; they were interviewed and recorded. Afterward, our conversations have been written down verbatim.

This paper is based on the analysis of the stories so collected: Both the representations and the practices depicted by the subjects are taken into account in order to understand their perspectives and their attitudes towards unwanted childlessness and NRT.

\section{Theoretical framework}

This section frames the analysis from a theoretical point of view. The analytical tools refer both to medical anthropology and to anthropology of reproduction.

Since my first approach to the interviewed people regarded their experience with NRTs, studies in anthropology of reproduction about NRTs have been examined. The specific focus was on the link between the reproductive technologies and the socio-cultural context. Accepting the cultural em-beddedness of biome- 
dical technologies, as well as the consideration that technologies were inti-mately connected with power relations (Webster 2002), these elements have been explored in the fieldwork. I therefore encompassed what Birenbaum-Carmeli and Inhorn outlined, namely that As-sisted Reproductive Technologies (ARTs)

"[...] are not 'immune' to culture as they make their way around the globe [...] Local considerations, such as support or deterrence on the part of local religious authorities, the provision of public funding for ARTs, inclusive versus restrictive admission criteria in IVF clinics, and favourable or distrustful media coverage, all impact the gendered and kinship relations within which local consumers seek out and deploy these reproduc-tive and genetic technologies" (Birenbaum-Carmeli, Inhorn 2009:3).

Inhorn had even invited to examine

"[...] the 'arenas of constraint' - or the various structural, ideological, social relational, and practical obstacles and apprehensions facing users of these technologies wherever they spread" (Inhorn 2007:187).

Following such suggestion, the analysis explored some arenas of constraints which informed the Italian context in the period taken into account. Particularly, the paper analyses the conditions which had led to the approval of Law 40/2004. In the opinion of the interviewed people, this regulation has been limiting the possible usages of NRTs and, in doing so, it has produced a specific representation of both NRTs and reproduction. Hence, the law has been considered as a "public transcript" which was conceived by some social groups in power, in order to control social reproduction as well (because of the strong link among individual and social reproduction ${ }^{3}$ ). Actually, in Scott's point of view, "public transcript" refers to the place

"[...] of material appropriation [...], of public mastery and subordination [...], of ideological justification for inequalities" (Scott 1990).

Thus, the specific representations and usages of NRTs imposed by such a public transcript, turned these technologies into biopower instruments through which "life enters history" and which differ-ent social subjects aimed to achieve. Namely, Law 40/2004 let the

"[...] entry of phenomena peculiar to the life of the human species into the order of knowledge and power, into the sphere of political techniques" (Foucault 2006:125). 
More recently, the concept of "biopower" was revised by Rabinow and Rose. These authors identi-fied three different orders of phenomena in it: The "truth discourses about the 'vital' character of living human beings" (also implying that authorities considered themselves competent to hold that truth); the "strategies for intervention upon collective existence in the name of life and health" and the

“[...] modes of subjectivation, in which individuals work on themselves under certain forms of authority, in relation truth discourses, by means of practices of the self, in the name of their own life or health, that of their family or some other collectivity, or indeed in the name of the life or health of the population as a whole [...]" (Rabinow \& Rose 2006: 197).

In such a more complex perspective, biopower should not be considered as the instrument of a single, monolithic group in power, but rather as a tool that could be strategically managed by different social subjects. Following this conception, it became important to analyse how people with unwant-ed childlessness approached NRTs and what strategies they performed when using them. This allowed to understand the complex networks of social forces surrounding NRTs and reproduction.

The statements of the interviewed people showed that they mostly considered NRTs as the answer to conditions already produced by an oppressive context.

Actually, in their perspectives, the biopower exerted by the governing groups was already oppressing them, independently of Law 40/2004: The "entry of life into the sphere of politics" seemed to be there ever since unwanted childlessness had appeared. Indeed, the disorder was interpreted as linked to economical, social, and political processes, which were considered as pathogenic forces in the social production of disease ${ }^{4}$. For these reasons, the critical approach of medical anthropology was very effective in this work when interpreting the disorder of people with unwanted childlessness. Actually, the disorder could be considered as a both biological and social phenomenon, for which "[...] the distribution of health services, the role of power in health care relationships and transactions (Waitzkin, 1991), and the social institutions and inequities [are] responsible [...]"(Good 1994:56). This work shares Good's point of view, according to which a critical analysis has to investigate "both the mystification of the social origins of disease wrought by technical terminology and metaphors diffused throughout medical language, as well as the 'social conditions of knowledge production' (Young 1982:277)" (Good 1994:57). 
Then, the research adopted a phenomenological perspective. The concept of a biological body detached from the socio-cultural context was substituted by the idea of embodiment, which "[...] is the subjective source and the intersubjective ground of experience" (Csordas 2003: 19). Even the perspective on disorders changed, referring to diseases as conditions that "represent coded messages in a bottle tossed on turbulent seas by the suffering and aggrieved [...]" (Scheper-Hughes 2000: 290).

From this point of view, unwanted childlessness was hypothesized to be an embodied practice people did not just passively suffered from, but they actively performed it, as an answer to a limiting social context. Such consideration recalls the concept of "structural violence", which is a kind of suffering

"structured by historically given (and often economically driven) processes and forces that conspire-whether through routine, ritual, or, as is more commonly the case, these hard surfaces-to constrain agency" (Farmer 2005: 40).

Therefore, the research had to identify the embodied answers that people with unwanted childlessness activate in order to react to this kind of structural violence. A theoretical perspective had to be considered, which showed their ability of conceiving and performing new strategies. Again, Scott's work on the "art of resistance" fitted the purpose very well. Indeed, the author analysed the discourses which were displayed behind the "official Story": Those discourses that subordinate or powerless groups performed offstage (Scott 1990). The concept of "hidden transcript" expressly defines low-profile-gesture politics which are creatively performed and are concealed, but constantly activated by subordinate groups for managing the domination practices exerted by elites.

"The hidden transcript is thus derivative in the sense that it consists of those offstage speeches, gestures, and practices that confirm, contradict, or inflect what appears in the public transcript" (Scott 1990:4-5).

Such an interpretation of the practices performed by the interviewed people also allowed to take a stand in the debates where the scholars who considered NRTs as biopower tools able to re-stabilise traditional and conservative family ideologies (Davis-Floyd \& Franklin 2001) opposed those who underlined the agency of NRTs' users in negotiating new and alternative ideologies (Greil 2002; Lock 1998; Saetnan 2000; Strathern 1992; Inhorn \& Van Balen 2002).

Actually, the analysis shows that also subordinate groups developed ways for exerting both biopower and agency, even though remaining within an arena of 
socio-cultural constraints. Therefore, reproduction and NRTs can become relevant instruments both for producing a conservative social order and for "re-producing" a different conception of it, depending on how they are used and who is using them.

\section{The Italian context in 2005-2008}

This paragraph portrays some social, economical, and political processes developed within the Italian context. Particularly, it explores the dynamics leading to the approval of Law 40/2004, in order to understand how such dynamics interacted with the embodied experience of people with unwanted childlessness.

Contentions about NRTs had arisen in the Italian public arena since 2001 when Silvio Berlusconi, a businessman, became Prime Minister. His party, a Christian-democrat and liberal-conservative one called "Forza Italia", won the elections along with some catholic and nationalist parties in the cen-ter-right coalition called "La casa delle Libertà" (House of Freedoms).

In that period, Berlusconi reaffirmed his support to the Pro-Life Movement ${ }^{5}$ and adopted a very strict regulation regarding "assisted reproduction". At the same time, the internal economic situation was alarming (namely, the GNP decreased and unemployment increased). However, in spite of such economic difficulties that delegitimized, at least partly, the government financial management, Ber-lusconi spent plenty of time focusing on the law about "medically-assisted procreation".

Some articles of this law are quoted in Annex 1: The law permitted the use of "medically assisted procreation" only "under the conditions and according to the modalities prescribed" and "when there are no other therapeutically effective means to remove the causes of sterility or infertility". Moreover, it protected "the rights of every involved subject, including the one to be conceived" and it allowed the access to "medically assisted procreation" only to "couples made up of people of dif-ferent sex who had reached majority, were married or living together, were of potentially fertile age and both living". In addition, it banned some practices, such as "heterologous techniques" and "em-bryo cryopreservation and elimination". Through this measures, the Government claimed to be do-mesticating what it had called a "procreative wild west".

However, prior to 2004, NRTs had already been regulated by Degan's newsletter and by the code of medical ethics in Italian public centres, while in private clinics NRTs were disciplined by self-regulatory guidelines. Such rules had given physi- 
cians a monopoly on NRTs (Bonaccorso, 2006) and had left a great deal of room for negotiation between them and their clients, setting up a relatively flexible system which allowed people some freedom to choose from among various therapeutic tools. Thus, before the approval of Law 40/2004, the meanings connected to reproductive practices had been mainly rooted in the negotiation processes involving social actors such as physicians, clients, and clients' relatives. This situation had permitted to apply NRTs in many different ways, until such technologies started to be defined as "wild" by some social powers (i.e., the centre-right and Catholic political parties as well as the Vatican). Such a representation of reproductive technol-ogies made it necessary to discipline the "wild" itself, so stage for the law was set.

It must be strongly underlined that Law 40/2004 was approved in a historical moment characterized by a socio-economic crisis, when the GNP decreased and unemployment increased. Seemingly, such a situation was not the reason for the interest showed towards NRTs by the groups in power. In fact, as the paper will show, it was just the specific historical and political conditions that justified the efforts to control reproductive practices and to hush up some embodied protests.

During the ethnographic work, the interviewed people heavily attacked the rules that the law im-posed on people already suffering from unwanted childlessness. Indeed, in their opinion, such rules were duplicating the affliction itself, namely the impossibility of breeding. What unwanted child-lessness meant for the people with unwanted childlessness is the focus of the first part of the work.

\section{Structural Violence, Reproduction and NRTs}

This paragraph analyses how the subjects with unwanted childlessness interpreted their own disor-der and how the latter could be framed as a socially produced disease. The inability to reproduce themselves took shape as an embodied practice, answering to a kind of structural violence, which was related to the productive field.

In the second part of the paragraph, the article shows how Law 40/2004 contributed to produce fur-ther constraints, proving to be a biopower instrument.

\section{The women's narrations about socially produced childlessness}

The accounts collected during the ethnographic fieldwork depicted unwanted childlessness as a so-cially, culturally and politically situated phenomenon, emer- 
ging from a highly critical context. In-deed, unemployment, economic insecurity, high competitiveness in the occupational field, the ex-tension of professional training, and the need for extra-specializations were described as pathogenic forces, considered substantial in the social production of unwanted childlessness (independently of the women's wealth: Actually, none of the interviewed subjects was living in poverty; rather, most of them had a medium-high lifestyle).

It has already been stated that the national economic situation was problematic: High levels of un-employment required that many young people become more specialised in their professional fields, and that they invest many more years in their education. They started obtaining Master degrees, tak-ing specialisation courses, and doing post graduate internships; however, even prolonging their pro-fessional training did not assure them a job, either an underpaid one or a temporary one.

The reports made visible a strong link between such conditions and unwanted childlessness. For instance, Fabiana's story was about a specialized physician married to a successful professional. They had been looking for a pregnancy for years, but in vain. About the causes of her previous childlessness, which had no organic origin (at least apparently), she argued:

"I saw it. I also clearly experienced it with my husband, who has always done a job which constantly puts him under big pressure; I observed how the outcomes of semen analysis changed in different periods! That is: In a period of great occupational stress vs holidays. The analysis was repeated after those wonderful holidays and it improved. Considerably".

So, unwanted childlessness specifically turns out to be an embodied practice, which refers both to an organic body (here represented by the "semen") and to an individual, social and political body $[7,8]$ affected by problematic occupational experiences.

Such situations seemed to impose a subtle form of "structural violence" (Farmer 2005) on women, because, even though their lives were not on the line, they were surely caught between specific so-cial limits (i.e., production vs. reproduction), from which they suffered. These mutually exclusive alternatives were tragically described by many women, who often turned to the concept of "stress" in order to explain that situation. It must be considered that their "stress" was never defined in psy-chological terms; rather, it was always the expression of an aggressive, competitive, and hard to manage context. 
For instance, Sabina directly connected the concept of "stress" to the origin of infertility. She was a thirty-eight-year-old woman who graduated from medical school and specialised in Orthopaedics; she was working in a hospital, but her salary was paid by a grant, so in 2007 she was earning only $€ 600$ monthly. Actually, she would not have been able to make ends meet without her partner's finan-cial support. Reflecting upon the social causes of unwanted childlessness, she said:

"Undoubtedly, stress affects infertility. Also because you reach a certain age and you feel your biological clock ticking; you feel you're about to miss the train, thus a great anxiety for pregnancy takes over and it surely affects ovulation. It's our present-day life-style. You must always be in the front line... because, if you don't fight while fully armed, you'll suddenly miss your train!"

The metaphors she used, mentioning fights and weapons, show that she perceived her situation in terms of violence. Moreover, Sabina explained that she felt overpowered when she recalled her many missed opportunities (her "missed trains"), so that she came to imagine time as a valuable and limited resource (a "clock ticking").

Similar considerations appeared in Bruna's accounts, where time seemed to flow quickly, so that she attributed her childlessness to age, although it had been considered idiopathic by the doctors. She reported she had given birth to a first daughter

"naturally, some years ago, six years ago; then, we realized that both me and my hus-band... yeah, then years passed by making checks, stuff..." I: "And then did you have a problem? You then realized..." Bruna: "... realized that I was thirtyeight years old... my fertility was almost over, yes. I had had a miscarriage in the meantime".

After a few years the woman and her husband managed to have a second-born, by means of an egg donation program which Bruna underwent in a different country. Both Sabina and Bruna talked about time in their discourses, and both of them referred to a social time (the time of "our present day-lifestyle" and that of the "years passed by making checks, stuff") and to a physiological time (that of "the biological clock ticking" and the "almost over fertility").

Also, many other kinds of time (always fugitive ones) were related to unwanted childlessness by the women. For instance, Luisa stated: 
"Yes, we have a frenetic life, we want to do everything! Now, above all, women have to do everything! We want to build a family, a home, to go shopping and, when children are born, to raise them. The job... [...] we want everything! It may be that our body says: 'Take it easy! Try to slow down, because I can only follow you so far!' Our life is anxiety: Since we get up in the morning till we go to bed. That's destructive, in my opinion".

Luisa was a forty-year-old woman and the mother of three children when she reported her story. She had discovered that her tubes were closed eleven years before, when she underwent surgery. Then she tried her first IVF three years later, and in that occasion several embryos could be made, as Law 40/2004 had not been approved yet. Luisa wanted to receive only the two of the best embryos: She immediately got pregnant and eventually had her first baby. Two years later she chose to implant three other embryos, and twins were born. In her above mentioned words, she referred to a new temporal horizon compared to the one described by Luisa and Bruna: It is the time going from sunrise to sunset, again compressed by the professional pace and many other commitments.

All these statements clearly represented a transformation of the productive world described by Mar-tin, where "time horizons of decision" are "shrinking" and time and space are compressed (Martin 1992). This way, infertility is revealed to be a commentary on the socio-political context; the symp-toms themselves could be read as a reaction to those critical conditions experienced as pathogenic forces. Afflicted bodies silently blamed those conditions, which were perceived as very substantial in the social production of disease .

Anna's narration (during which her husband Giovanni was present) shows that also people affected by "physiological" forms of suffering attribute them, at least in part, to social problems. Even though Giovanni's azoospermia appeared to have nothing to do with social issues, Anna claimed:

“In my opinion, it isn't a coincidence. Evidently, there isn't any space -mental and physical space- for all these... at least with our life style. I see that really it's always a race to the week-end, isn't it? You begin your week thinking about the week-end and then, when the week-end arrives, you do so many things... or you don't do anything, but you overload it with your expectations which won't be fulfilled. And this way you don't live".

Note that Anna is a teacher who likes her job, but she stated that it was very demanding from an emotional point of view and it was not well paid; Giovanni, on 
the other hand, is a freelance archi-tect and had a very fast-paced life. Although they were neither poor nor marginalised, their life was very stressful. Feeling overloaded, Anna felt as if she were "suspended" in a "limbo" where time and space totally compressed and annihilated her. Despite that, Anna's affliction generated a person-al revolution and activated some creative and subversive capabilities, so that she acquired new awareness: She then asserted that her children (she gave birth to twins) were born from this renewed existence.

Re-shaping life in an unexpected way meant also that affliction could become a cultural opportunity, which was not annihilating people, but leading them to transform their suffering into a critical attitude towards their own existence, as well as the society in which they live. Interviewed people reacted in various ways, usually trying to imagine new social and cultural possibilities. In fact, many women contemplated other forms of kinship or other social organizations (i.e., they often referred to different lifestyles, such as those performed in the countryside, in Northern Europe, in past times or by other populations). For example Sabina, the orthopaedic doctor we mentioned before, recalled her encounter with a Romany girl, who was almost fifteen years younger than her and already mother of seven children. Remembering that moment, Sabina kept comparing herself to the girl and facing an unrealized chance, a choice that was not performed, but that might have been made:

"Let's count: nine pregnancies, seven childbirths and the eldest son was ten years old. So, she [the Romany girl] was first pregnant when she was fifteen [...] Because then, just imagine: When she was twenty-five, she already had seven children. When she is as old as me, she'll have a soccer team, with bench too [...] So, it's obvious: I see these mothers... I'm always checking their birth-dates of the mothers and comparing them with mine..."

Exploring other socio-cultural realities a trend can be seen towards other interpretations of repro-duction, at the same time individual and social reproduction. Therefore, the fact of imagining -and maybe performing- other possibilities could have given rise, sometimes literally, to "emergent forms of life" (Rose 2007), which would have deeply threatened groups in power. On the other hand, those groups were aiming to consolidate a specific social order, in which their positions could be preserved. 


\section{Law 40/2004 as a biopower device}

As it was stated before, the Italian economic difficulties could have delegitimized, at least partly, the Government. According to ethnographic data, unwanted childlessness (conceived as a socially produced phenomenon) contributed to point out such a crisis; moreover, the usages and the interpre-tations of NRTs performed by women could have become a political instrument, able to challenge the sociocultural borders both in an imaginative dimension (as Sabina's comparison exemplifies) and in an embodied dimension (because other gametes, other embryos and other reproductive practices could have entered women's bodies). Concerning those communities that perceived themselves as endangered, Lock and ScheperHughes affirmed that "boundaries between the individual and po-litical bodies become blurred, and there is a strong concern with matters of ritual and sexual purity, often expressed in vigilance over social and bodily boundaries" (Lock \& Scheper-Hughes 1987). The enacting of Law 40/2004 and the consequent reinterpretation of reproductive practices seemed well placed in the political context described above.

Indeed, according to the women's narrations, the law was a socio-political device aiming to define the limits of reproductive options, by further narrowing down the chances of those subjects who were already affected by such a reduction. In doing so, the regulation reaffirmed just the same world where horizons of decision were impoverished.

In her narration, Anna specifically referred to a restriction of freedom, when she said:

"I don't understand why I should submit to rules, I do not agree with. This way my freedom will only be limited".

The metaphoric expressions used by another woman, Elisa, were even more effective. She stated:

"Nobody should talk about these things and then issue a law as the one on assisted procreation one, that clubs you [...] Anyway, I think that... why clipping the wings of people, of the very same people who already have problems and have decided to do something? [...] It would be just as well if they said 'you can't procreate any more, go abroad, sort it out yourself: Here, it is forbidden!' They may as well do that. Women are really buried, this way". 
Expressions such as "to clip people's wings" and "to bury a woman" depict a sort of immobility im-posed on women, whose horizons seem to disappear "underground" ("women are really buried").

For that reason, the prohibition on cryopreservation of embryos became a metaphor of the whole law in the opinion of many women. Indeed, the interviewed women represented each embryo as a potential child that the regulation disposed of. Far from being just an imaginary perception, that rep-resentation is embodied in the women's experiences. As Luisa's story showed, cryopreservation of many embryos allowed her to choose how to manage some phases of her in vitro fertilization, such as the phase of transfer. She could decide how many embryos had to be transferred into her womb, because she underwent IVF when the law had not been approved yet. She said:

"That was the focal point of this law: The limitation to only three embryos. I say, con-sidering my experience: 'Who knows, I probably wouldn't have been able to do it!'[...] Thus, this is why they have few opportunities [...] Then, if I've got ten cells, I'll be able to choose two of them or one, or three. I've got one choice in ten!"

So, the reduction of the individual's opportunities is considered as the "focal point" of the whole law.

In women's considerations, this issue was expressed also by other prohibitions imposed by the law, like the ban on the donation of gametes (Law 40/2004,II,art.4). Such limitation led to the impossi-bility of any pregnancy for some people: As shown by the case of Bruna, whose fertility "was al-most over" and who would not have been able to conceive children, if she had not gone abroad. This was also the case of Anna, because Giovanni's azoospermia did not allow them other effective usages of NRTs (in fact, they had to go abroad too). Unfortunately for them, the donation of gam-etes, more than other practices, requires to go beyond body boundaries, as it involves a third party in the process of reproduction. Moreover, it could have shaped new kinds of kinship, further threat-ening the "Italian identity" of that community already perceived as endangered by the Government. So, it is plain that the latter provided for banning it.

The defense of traditional family relationships was further asserted by other articles of the law, as the second one, concerning "Access to the techniques". It stated that only "people of different sex having reached the age of majority, married or living together, of potentially fertile age and both living can have access to the techniques" (Law 40/2004,II,art.5). The kind of kinship depicted by this article of the law is obviously that of the monogamous and heterosexual family; homose- 
xual couples or single women, who could again destabilise the social order, were excluded from the re-productive world. Although in women's opinions this point was more controversial than the previous one, it is interesting to observe a certain openness towards these kinds of parenthood, which women had not usually considered before. Bruna told the story of a homosexual friend of hers, who underwent donation of gametes practices, as she did. In her narration, Bruna described both their experiences and, in doing so, she reduced the demarcation between heterosexual and homosexual parenthood.

"Look, I have a friend who has just called me, she is expecting, she is in her seventh month of pregnancy and she went... she is homosexual and she went to Holland.

I'm sure she will be an excellent mother, she and her partner".

Such a representation of "good parenthood" challenges the one proposed by the regulation. Accord-ing to the women, the latter was due to the pressure of the Vatican on the Government: The law aimed at adopting a point of view closer to the Catholic one, acting on the real ethic dimension. About that, Bruna stated that "the point is that we have the Pope here in Italy, so..." and Sabina stressed: "In my opinion, the restriction we have is due to the fact that we have the Pope in our Country and this prevents us from approving certain things". Notice that Catholic faith was not crit-icized in itself (many women declared to be churchgoers); rather, women argued against the imposi-tion of a univocal interpretation of NRTs that would have limited their procreative possibilities. So, even though Anna considers herself as belonging to a Catholic family, she deliberately decided not to baptize her twins, because of the position expressed by the Church on NRTs; on the other hand, Elisa baptized her set of triplets and very often confided her reproductive troubles to her parish priest. Even more interesting was what Sabina said about the Holy Writ, which, in her opinion, did legitimize donations of gametes.

"I haven't read the Bible, but... a friend of mine, who had serious problems like me ('cause she had three miscarriages before having two children, that's why she really supported me) [...] we were speaking about donation of gametes and she told me that a man in the Bible - I don't remember who he was, maybe the very old one; maybe it was Moses or Sarah's husband... I don't remember who he was; anyway, it seems that he - now I don't remember who he was - anyway, he was very old, he wasn't able to have children any more and his wife went with another man, so their progeny could have gone on. Anyway, a case of donation of gametes does exist!" 
This way, Sabina and her friend worked out together a narration that could both link their experi-ence to Catholic tradition and suggest alternatives to the interpretation promoted by the law.

Generally, the alliance between the Government and the Catholic Church in shaping the regulation was often underlined and strictly condemned by the women, who plainly spoke about some ex-changes between parliamentary Catholic fringes and "La casa delle Libertà". About that, Luisa said:

"I think that it [the law] was the outcome of tactics that are definitely political, in re-turn for other kinds of favours. It's like: I give you my votes, you support me for other things [...] I mean, the Government was fully supported by the Church and the Church asked other... other favours in return. And since there was this law that did not... this... well, no law existed before. So, it was right to regulate NRTs, but they have been regulated in the wrong way! In the end, it penalizes science and women."

Here, the contrast between groups in power and women is clear: In Luisa's words, women seem to be subordinated to macroscopic logics (the "political tactics" and the "other favours").

So, women's disappearance cropped up more explicitly out: Such disappearance did not refer to an unspecific "womanhood", but rather to that of the embodied subjects who "were inside the issue" or who "were really touched" by it (as Luisa stated in another point of her interview). When she was talking about her participation to some public meetings concerning Law 40/2004, Anna said:

“When you tell your story, they usually reply ‘Ok, but yours is a story apart!' But we all are 'a story apart!' I could introduce you to ten thousands people, who are 'a story apart'. This law speaks about stories apart!”

The expression "a story apart" focuses on the embodied experiences, upon which the law was su-perimposed ("this law speaks about stories apart"), in order to silence them. One of the women met-aphorically expressed such process of hushing up, when she said:

"If only I could have been on TV! I don't know what I would have given, really. Be-cause, what I noticed was just that, I say: 'Good heavens! All these programs are there, talking about me, about me! About us. About us! And none of the contributors was ef-fectively touched by this thing!" 
Exclusion practices that eclipsed real experiences were pointed out by the women in many other ways, for instance when they spoke about the concept of "childhood". In the law, the unborn was conceived as a subject with legal rights, since "the rights of every involved subject, including the one to be conceived" were defended (Law 40/2004,I,art1). However, in the parents' opinion, the child, even "one to be conceived", was the expression of its parents and their kinship, of their love and their embodied way to be. As a matter of fact, the women did not contest the pushing forward of the emergence of a new individual since the very beginning of pregnancy (indeed, they usually supported the idea that a baby appeared in their womb since the first months of pregnancy); the concept they did not agree with is that the baby was conceived as a generic "unborn", a separate legal entity from themselves. About that Fabiana stated:

“In my children, I really glimpse some manifestations, ways of doing, gestures that remind me of their grandparents, their uncles, and obviously myself and my husband. Especially us. And that's really a beautiful thing: That is, you indisputably see your person and your projects, in your children".

Obviously, such interpretation was focusing on a relational dimension, which shaped the child; in-stead, the sentence expressed in the first article of the law seemed to free the "unborn" from the networks in which it he was placed. This way, it became subject to different jurisdictions (such as "Nature" or "Law") and it met the expectations of several interested parties that manage such juris-dictions.

Note that the meaning given to the concept of "human life" by the law overlapped with the one pro-posed by an important teaching of the Congregation for the Doctrine of Faith ${ }^{6}$, called Donum Vitae (although the two interpretations did not completely match). In that encyclical, the Vatican express-ly claimed that an embryo is due the same dignity as a human person, thus it could neither "be wished nor conceived as the product of medical and biological techniques" (Donum Vitae 1987). Thus, Donum Vitae attempted to remove the "unborn" from a biomedical frame, even if it shaped the human being in such a way (it must be kept in mind that Donum Vitae explicitly turns to biolog-ical terminology when referring to life processes): In both cases, life was deprived of its embodied components and reframed under other powers, which did not concern the desires, the fantasies, the choices -in a word, the stories- of the potential parents.

That conception clarifies why, according to the law, only "cases of unexplained sterility and infertility documented by a medical act, as well as cases of sterility and infertility established and certified by a medical act" (Law 40/2004,II,art.4) 
may have access to NRTs. Above all, the law re-asserted the biomedical management (by referring to a "medical act") but, at the same time, it satis-fied the Church at least in part, considerably limiting the usage of NRTs. Actually, although Donum Vitae rejected any kind of intervention, a complete ban of such practices would have been virtually impossible for the State; however, the reference to a pathological condition may be meant to recall the idea of a health problem, which would have not challenged the divine procreative power, as oth-er practices seemed to do (it is the case of embryonic screening which the law forbids). In the end, it is a specific interpretation of technology, which can no longer be considered a means of prevention, to be forbidden (the law aims at avoiding the implantation of embryos with genetic defects in order to spare women either from starting NRT procedures that are destined to fail because of these de-fects, or from giving birth to ill babies).

Finally, the regulation reaffirmed what NRTs meant, which was the last support to divine/natural "procreation", nothing to do with the processes of parental freedom or choice. This way, the intents of the groups in power were satisfied, by symbolically eliminating those who challenged the existing social order, with both their embodied sufferings and the "new forms of life" that they could have produced. Hence, the law can be considered both a biopower instrument able to shape society by controlling its reproductive options, and a way to re-balance the forces controlling these options (Government parties and the Catholic Church rather than physicians and individuals).

\section{Hidden transcripts: Practices for biopower re-appropriation}

This analysis stated above that the groups in power strategically disciplined NRTs in order to pre-serve a particular kind of control; on the other hand, NRTs were viewed by women with unwanted childlessness as a chance to exert their agency, in order to overcome their affliction and to give new meanings to their life.

The analysis also outlined that scholars in social studies have worked out opposite interpretations of NRTs, which are believed by some to be empowering devices, but are considered oppressive in-struments by others .

While reflecting on the opportunity for infertile people to negotiate their own role, Saetnan (2000) does not consider assisted fertilization as a practice free from socio-cultural implications. Neverthe-less, it is a way (both official and unofficial) people with unwanted childlessness can work out their personal interpretations of their lives and take control of them again through a set of emotional, cul-tural 
and political meanings. It is interesting to observe that, in the Italian case, women became more involved in this task when procedures were more limiting, because in such situations they were almost compelled to turn to other strategies, if they wanted to exert their own agency.

Thus, even if the approval of Law 40/2004 apparently seemed to confirm what Davis-Floyd and Franklin said (i.e. that NRTs lead to the re-stabilisation of traditional and conservative family ideo-logies, Davis-Floyd \& Franklin 2001), actually the law generated infra-political acts as well as po-litical fights against the social order.

In fact, references to real "fights" constantly surfaced in the interviewed women's narrations: The first goal of these battles was the acknowledgement of the women's embodied presence, with the aim of giving new meanings to the experiences of unwanted childlessness. For instance, Anna said she had invested huge resources in her fight for reconquering the right to parenthood:

"We really found ourselves spending a lot of money, doing things surreptitiously,

fighting, in order to obtain these children".

For her part, Luisa reasserted her own involvement in a desperate dispute, that she could not exempt from:

"I fought against that law [...] Really: I tilted at windmills!".

So, it seemed that, by exasperating the coercive and conservative potentialities of reproductive technologies, the law had exacerbated different and even opposite interpretations, insomuch that even people with unwanted childlessness who shared Catholic values (considered as inscribed in Law 40 by many people) rose up against it. This way, they reacted against the structural violence that had been imposed upon them twice (via the social setting and, then, via the law), by creatively condemning and symbolically re-interpreting the same weapons used by their "enemies". The strat-egies shaped by women for taking part in that dispute have been manifold and many-sided. Some-times, these strategies were public initiatives, aiming to sensitize the population to unwanted child-lessness; sometimes, they have resulted in infra-politic acts, such as the enacting of those practices banned by the law.

Regarding public actions, even though these women were not political militants, many of them said to have done their best for sensitizing the grassroots after the approval of the law. So, they attended public meetings and took part in the sign-in campaign asking for a referendum to abrogate the law. For instance, Anna, 
reported to have organized "some evening gatherings, me with my baby bump, to canvass for the referendum". Luisa also reported:

"I fought against this law. I mean that, when I read the article about the bill on the newspaper, I said: 'That cannot pass, let's hope it'll never pass!' Then, when it passed, I said: 'My God, let's hope they'll do a referendum to abrogate this law!' Afterwards, I tried to speak to all the people I know about the wrong issues of this law, but I some-times ran into the buffers".

Concerning infra-politics, many "offstage" practices have been enacted, producing a slow and quiet re-distribution of power, just by virtue of their poor visibility. Even if this attack remained a sym-bolic weapon in some cases, in other situations people actually performed banned practices, using NRTs to their advantage in order to assert individual freedom. It is what Bruna did abroad, when she received embryos generated by the egg cells of another woman; it is also what Anna did, when she was fecundated by spermatozoa of unknown donors in Spain. So, even carrying out some par-ticular kinds of assisted fertilization programmes became a "hidden transcript" which challenged the social order. By means of their practises, then, people with unwanted childlessness came up with other discourses, values, relationships, and alliances, which enabled them to turn the socio-cultural context to their advantage. For instance, many interviewed women strategically changed their gy-naecologists or fertility clinics, choosing specialists with whom they could start a useful cooperation, in order to pursue their own goals. Anna said that she did not feel comfortable in the first clinic where she went, because her role there was that of a subordinate individual, without any negotiation power. Thus, she chose another place, where her "patienthood" was completely different. In that case, the gynaecologist welcomed her requests and they established an alliance almost bordering on the illegal. Actually, before the law approval, the doctor shortened her operations' timetable (as much as possible), in order to allow her to undergo the donation of gametes; then, he administered her the forbidden treatment after the approval of the law, by taking advantage of the lapse of time between the approval itself and the coming into effect of the regulation; finally, after March 10th , he suggested her to go abroad in order to access the necessary therapies.

For the interviewed women, going abroad in order to undergo a pre-implantation diagnosis or a do-nation of gametes became the opportunity to pursue the craved parenthood but, at the same time, it gave them the chance to perform an alternative way of being, able to escape from the borders de-fined by the groups 
in power. Therefore, these women embodied (metaphorically, but also practical-ly) that "Outside" that the Government feared, challenging the purity of identity that the groups in power aimed to build.

Thus, when Anna and Giovanni decided to go abroad to undergo treatment and to receive a dona-tion of male gametes (thereby circumventing the restrictions imposed by the Italian law), they were also ascribing new meaning to both their reproduction and their lives. By performing the donation of gametes, they were affirming that they did not believe that parenthood was embedded in genes (otherwise Giovanni would have not been the legitimate father of his own children), and they were working out new interpretations of parenthood. Giovanni said:

"I think the donor is... I don't know who he is or what he can be in his life; but he's a person who performed an act of love. And only something good can come from an act of love, can't it? Then, we can make a more sentimental comment, that is: These chil-dren are the result of the love between me and Anna. They were born because of this, truly."

From this point of view, which Anna shared, it is emphasized the idea of that relational childhood mentioned above; consequently, they supported the concept of a parenthood generated "by love", and not by biological ties. It is interesting to note that in their opinion, also genetic elements ac-quired new meanings as Anna and Giovanni showed when they said:

"In any case, Spain remains in our hearts: Sometimes we say to the children: 'Ah, you've got Catalan chromosomes in your DNA!"”.

In a "molecularised world" crossed by "molecular biopolitics" (Rose 2007), Anna and Giovanni took possession of their own lives by filling chromosomes, genes and embryos with stories of hope and fight.

The "Outside" (symbolized here by Spain) is in the hearts of Anna and Giovanni, while at the same time it becomes a constitutional part of their children: Not only is it embedded in their DNA, but it is really that "External" -that Wild West so dreaded by the Church and by political forces- which made it possible to give birth to the children. Through genes, the babies inherit (in a naturalised way) the "Outside" which Anna and Giovanni have been able to conquer during their existence, so that those children are the living proof of both the power that their parents obtained by "taking the Outside" and of the thick meaning of their lives, which are no longer bare, but full of historical and social dynamics. 


\section{Conclusions}

This article explored the representations and the practices concerning unwanted childlessness and Law 40/2004, carried out by people who underwent NRTs in Italy.

The analysis of these people's accounts showed that unwanted childlessness was not conceived only as a biological condition, but also as a socio-cultural disorder. Such an affliction was depicted as an embodied practice reacting to the structural violence imposed by the socio-economical context. Moreover, unwanted childlessness led afflicted people to imagine other reproductive possibilities. By accessing NRTs before the approval of Law 40/2004, interviewed people could concretely activate new reproductive possibilities, negotiating only with their physicians.

Obviously, the groups in power perceived such a situation as a threat to the social order. They answered by imposing a redefinition of NRTs and, more generally, of reproduction: Law 40/2004, which could be considered as a "public transcript". Given these dynamics, the approval of Law 40/2004 could be fully justified in a period of socio-economical crisis: It was a biopower instrument managed by the groups in power that allowed them to monitor both the social and the bodily boundaries. Moreover, it brought back the "reproductive wild west" to the previous order, even if, in doing so, it also reproduced the structural violence incidental to it (and, consequently, the unwanted childlessness of those people who were already suffering from it).

At a first glance, such situation seemed a failure in reaching the goals of the interviewed people, but the ethnographic work showed that these people were able to figure out new ways for exerting their own agency. They devised some "infra-political" actions, through which they could re-mould, at least partially, their own reproductive destinies. This kind of resistance produced a slow and quiet re-distribution of reproductive powers. It remained a symbolic weapon in some cases, while in other situations it legitimized people to actually perform some banned practices. As mentioned before, it is what Bruna did abroad, when she received embryos generated by the egg cells of another woman; it is also what Anna and Giovanni did, when they decided that Anna would be fecundated by spermatozoa of unknown donors in Spain. For the interviewed people, going abroad in order to undergo a donation of gametes became the opportunity to pursue the craved parenthood, but, at the same time, it gave them the chance to perform a new way of being, able to escape from the borders de-fined by the groups in power. In their own experiences, people with unwanted childlessness embod-ied 
(metaphorically, but also practically) that "Outside" that the Government feared, challenging the identity boundaries that the groups in power aimed to build. Such an "Outside" was not just depict-ed in their practices, nor just in their discourses; rather, it was really structured in their somatic bod-ies, as well as in those of their children.

Finally, these infrapolitics, by allowing people with unwanted childlessness to create new reproduc-tive worlds, gave rise, sometimes literally, to "emergent forms of life" (Rose 2007).

\section{Annexe I. Law 40/2004 - Some of the most relevant articles (Benagiano \& Gianaroli, 2004)}

\section{TITLE I. GENERAL PRINCIPLES}

\section{Article 1.}

1. With the aim of facilitating the solution of reproductive problems consequent to human sterility and infertility, it is permitted to utilize medically assisted procreation, under the conditions and ac-cording to the modalities prescribed in the present law, that ensures the rights of every involved subject, including the one to be conceived.

2. Resorting to medically assisted procreation is only permitted when there are no other therapeuti-cally effective means to remove the causes of sterility or infertility.

Article 2.

1. The Minister of Health, having consulted the Minister of Education, Universities and Research, can promote research activities on the pathological, psychological, environmental and social causes of sterility and infertility phenomena and facilitate the interventions necessary to remove them, as well as on ways to reduce their incidence; the Minister can also promote studies and research on techniques of cryopreservation of gametes and can furthermore promote campaigns of information and prevention of sterility and infertility phenomena.

2. For the purposes specified in subsection 1, the present law authorizes the maximum expenditure of 2 million euro, starting in 2004.

3. Description of the financial means.

Article 3. Description of the modification necessary to Law 405/1975.

\section{TITLE II: ACCESS TO TECHNIQUES}

Article 4.

1. It is permitted to utilize techniques of medically assisted procreation only when the impossibility to otherwise remove the impediments to procreation has been established and, in any way, this utili-zation is limited to cases of unexplained sterility and infer- 
tility documented through a medical act, as well as to cases of sterility and infertility established and certified through a medical act.

2. Techniques of medically assisted procreation re applied on the basis of the following principles:

a) gradually, in order to avoid resorting to interventions with a more profound degree of technical and psychological invasiveness for the persons to whom they are destined, thereby following the principle of lower invasiveness;

b) through informed consent, to be realized according to article 6 .

3. It is forbidden to utilize heterologous techniques of medically assisted procreation.

\section{Article 5.}

1. Whereas what is established by Article 4, subsection 1, remains valid, access to medically assisted procreation is granted to couples made up of persons of different sex having reached the age of majority, married or living together, of potentially fertile age and both living.

\section{Article 6.}

1. To achieve what is spelled out in subsection 3, before starting and during each phase of applica-tion of techniques of medically assisted procreation the physician informs in a detailed manner the subjects referred to in Article 5 on the methods, bioethical problems and possible health-related and psychological side effects that may arise out of the application of said techniques, on the probabili-ties of success and on the risks deriving from them, as well as on the relevant juridical consequences for the woman, the man and the infant to be born. The couple must be made aware of the possibility to start procedures to adopt or receive in custody a child, according to the law of 4 May 1983, No. 184 and subsequent modifications, as an alternative to medically assisted procreation. Information contained in this subsection and those relating to the degree of invasiveness of techniques for the woman and the man must be provided for each applied technique and in such a manner as to guarantee the formation of a conscious and consciously expressed will.

$[\ldots]$

\section{Article 14..}

1. Embryo cryopreservation and suppression are forbidden; however, the provisions of the Law of 22 May 1978, No. 194 stand valid.

2. Techniques of embryo production, taking into consideration technical-scientific evolution as well as that provided in Article 7, subsection 3, must not create a number of embryos exceeding that strictly necessary to a unique and contemporary implant, at any rate, never to exceed three.

3. If embryo transfer in the uterus cannot be carried out for serious and documented reasons of 'force majeure' having to do with the health of the woman and impossible to predict at the time of fertilization, it is permitted to cryopreserve the embryos in question up to the date of transfer to be carried out as soon as possible.[...] 


\section{Notes}

1. Law 40/2004 "Norms in the matter of medically-assisted procreation", Gazzetta Ufficiale no.45, 24th February 2004. Some of the most relevant articles of the law are quoted in Annex 1.

2. All names mentioned here are pseudonyms.

3. Davis-Floyd and Georges' studies underlined that "[...] the future of any given culture depends heavily on women's procreative abilities" and that "these abilities carry strong social significance" (Davis-Floyd \& Georges 1996:1).

4. The definition of social production of disease was first introduced by Kleinman and it was then adopted by Good (Good 1994).

5. The activist movement in medical-ethics which maintains that human fetuses and embryos are already people and therefore have a right to live.

6. The oldest of the nine congregations of the Roman Curia, which oversees Catholic doctrine.

\section{References}

Benagiano, G. \& Gianaroli, L. (2004). The new Italian IVF legislation. In Reproductive BioMedicine Online, 9(2), 117-125.

Birenbaum-Carmeli, D. \& Inhorn, M.C. (2009). Introduction: Assisting Reproduction, Testing Genes: Global Encounters with New Biotechnologies. In Birenbaum-Carmeli, D. \& Inhorn, M. (Eds.), Assisting reproduction, testing genes: global encounters with new biotechnologies. New York, Oxford: Berghahn Books.

Bonaccorso, M. (2006). Programmes of Gamete Donation: Strategies in (Private) Clinics of Assisted Conception. In M. Unnithan-Kumar (Ed.), Reproductive Agency, Medicine and the State. New York, Oxford: Berghahn Books.

Csordas, T.J. (2003). Incorporazione e fenomenologia culturale [Embodiment and cultural phenomenology]. In Mattalucci-Yilmaz, C. (Ed.), Corpi, Annuario di Antropologia [Bodies, Annual of Anthropology]. Roma: Meltemi.

Davis-Floyd, R.E. \& Franklin, S. (2001). Reproductive Technologies. In T. Montgomery (Ed.), Routledge International Encyclopedia of Women. New York: Routledge.

Davis-Floyd, R.E. \& Georges, E. (1996). On Pregnancy. In Encyclopedia of Cultural Anthropology. New Haven, CT: Human Relations Area Files.

Farmer, P. (2005). Pathologies of Power. Health, human rights, and the new war on the poor. Berkeley and Los Angeles, London: University of California Press.

Good, B. (1994). Medicine, rationality and experience. An anthropological perspective. Cambridge: Cambridge University Press.

Greil, A. (2002). Inferitle Bodies: Medicalization, Metaphor, and Agency. In M. Inhorn \& F. Van Balen (Eds.), Infertility around the Globe. Berkeley, Los Angeles, London: University of California Press.

Inhorn, M.C. (2007). Reproductive Disruptions and Assisted Reproductive Technologies in the Muslim World. In Inhorn, M.C. (Ed.), Reproductive disruptions, Gender, Technology, and Biopolitics in the New Millennium. New York, Oxford: Berghahn Books. 
Inhorn, M. \& Van Balen, F. (2002). Infertility around the Globe. Berkeley, Los Angeles, London: University of California Press.

Lock, M. (1998). Perfecting Society: Reproductive Technologies, Genetic Testing, and the Planned Family in Japan. In M. Lock \& P. Kaufert (Eds.), Pragmatic Women and Body Politics. Cambridge: Cambridge University Press: 206-239.

Martin, E. (1992). The End of the Body? American Ethnologist, 19(1), 121-140.

Rabinow, P. \& Rose, N. (2006). Biopower Today. BioSocietes, 1, 195-217.

Rose, N. (2007). The Politics of Life Itself. Biomedicine, Power and Subjectivity in the Twenty-First Century. Princeton: Princeton University Press.

Saetnan, A. (2000). Women's Involvement with Reproductive Medicine: Introducing Shared Con-cepts. In A.R. Saetnan \& N. Oudshoorn \& M. Kirejczyk (Eds.), Bodies of Technology. Women's In-volvement with Reproductive Medicine. Columbus: Ohio State University Press.

Scheper-Hughes, N., \& Lock, M.M. (1987). The Mindful Body: A Prolegomenon to Future Work in Medical Anthropology. Medical Anthropology Quarterly, New Series, 1(1), 6-41.

Scheper-Hughes, N. (2000). Il sapere incorporato: pensare con il corpo attraverso un'antropologia medica critica [Embodied knowledge: thinking with the body in critical medical anthropology]. In R. Borofsky (Ed.), L'antropologia Culturale Oggi. [Assessing Cultural Anthropology]. Roma: Mel-temi.

Scott, J. C. (1990). Domination and the Arts of Resistance Hidden Transcripts. New Haven, CT; London: Yale University Press.

Strathern, M. (1992). Reproducing the Future. Essays on anthropology, kinship and the new reproductive technologies. Manchester: Manchester University Press.

Webster, A. (2002). Innovative Health Technologies and the Social: Redefining Health, Medicine and the Body. Current Sociology, 50(3):443-57. 